\title{
CrimRxiv
}

\section{Timing is Everything: The COVID-19 Outbreak as a Trigger Event for Sinophobic Hate Crimes in the United Kingdom}

Sandy Schumann

Published on: Apr 15, 2021

DOI: $10.21428 / \mathrm{cb} 6 a b 371.283 a 70 a 2$

License: Creative Commons Attribution 4.0 International License (CC-BY 4.0). 


\section{Research Summary:}

We assessed whether the COVID-19 outbreak in the UK served as a trigger event, associated with a rise in sinophobic hate crimes. Police-recorded hate crime data from London (Study 1) showed that race hate crimes increased four months after the first COVID-19 case was reported in the UK. However, as the data was aggregated across different ethnic and racial groups, it is possible that the trend did not reflect sinophobic hate crimes. Study 2, a victimization survey completed by East Asian, South Asian, African, and Caribbean persons who lived in the UK $(N=393)$, provided more nuanced insights. After the COVID-19 outbreak, individuals of Chinese or East Asian descent had a higher likelihood of being hate crime/incident victims than members of other ethnic minority groups. Specifically, we found evidence for the targeted victimization in February 2020. Before the pandemic, the likelihood of hate crime victimization did not differ between Chinese/East Asian persons and other participants.

\section{Policy Implications:}

The results point to important implications for policy and practice. Echoing previous studies, we recommend that hate crime prevention strategies consider when hate crimes are most likely to occur. The period shortly after the discrete event appears to pose a particular risk for targeted victimization, even for trigger events that last several months and for which the perceived ingroup threat is initially hard to define. Furthermore, we highlighted similarities and differences in hate crime victimization for the Chinese/East Asian community and members of other ethnic minority groups. Only the survey study and not the police-recorded crime data allowed for this conclusion. To enhance abilities to address the victimization of all ethnic communities in equal measure and successfully, official hate crime statistics in the UK must record victim's ethnicity at a more granular level.

Keywords: COVID-19, hate crime, trigger event, sinophobia

\section{Introduction}

COVID-19 first emerged in Wuhan, Hubei province, China, in December 2019. As the novel corona virus spread around the world, news reports drew attention to crimes targeting individuals of Chinese or East Asian descent. For example, a Singaporean student was injured in an attack in central London; the perpetrator shouted, 'I don't 
want your coronavirus in my country' (BBC, 2020). According to Sky News, "the rate of hate crimes against Chinese people [in the United Kingdom (UK)] between January and March [2020] was nearly three times that of the previous two years" (2020; see also Murphy, 2020). Similar observations were made in the United States (ADL, 2020; Russell, 2020). Summing up these accounts, it appears as if the COVID-19 outbreak served as a trigger event that elicited a rise in sinophobic hate crimes. However, beyond anecdotal evidence (e.g., Gover et al., 2020; Tessler et al., 2020) and selective analyses of crime data in news outlets, this claim has not been systematically examined. The present study aimed to address the gap in the literature, focusing on the United Kingdom.

Specifically, we analyzed police-recorded hate crime data from London (Study 1) and conducted a victimization survey in the UK (Study 2) to investigate whether individuals of Chinese or East Asian descent were more likely to be hate crime/incident victims in early 2020, than before the pandemic. We also assessed if individuals who describe their ethnicity as Chinese or East Asian had a higher likelihood of victimization than persons of South Asian, African, or Black Caribbean descent, after the COVID-19 outbreak (i.e., targeted victimization). Finally, we explored when, and for how long after the first COVID-19 case was reported in the UK, evidence of increased or targeted sinophobic hate crime victimization could be identified.

As will be elaborated on below, answering these research questions provides relevant insights for practice and theory. To date, most local and national hate crime prevention strategies emphasize the importance of responding to crime hot spots, that is, where hate crimes occur (e.g., Hampshire Police and Crime Commissioner, 2017; Home Office, 2016; 2018a; MOPAC, 2017; Safer Stronger Doncaster, 2017; Stanko, 2004). By examining a unique event type (i.e., that lasted several months and for which the perceived ingroup threat was initially hard to establish), we seek to advance existing work and highlight that it is equally crucial to consider when biased motivated crimes are most likely to happen. In addition, there is a paucity of comparative research on hate crime victimization, especially such studying the experiences of Chinese/East Asian persons. We conceptualize trigger effects as targeted - rather than only increased - victimization of specific social groups, and investigate distinct patterns of hate crimes against the Chinese/East Asian community to inform prevention measures.

\section{Hate Crimes and Trigger Events}

The term hate crime was first introduced in the 1980s and refers to a criminal offence motivated by bias, prejudice, stereotypes, or hate (Green et al., 2001). Victims are 
targeted because of their (perceived) disability, religious, racial, ethnic or linguistic background, their gender or sexual orientation (OSCE, 2020). National legislations vary with regards to the behaviors that may be defined as hate crimes (OSCE, 2020). In the UK, where all data for this paper was collected, personal and property crimes as well as hate speech - the use of "threatening, abusive or insulting words or behaviour" with the intent to threaten or incite violence, intimidate, and abuse (Public Order Act 1986, Section 4) - are classified as criminal offences.

Among other factors, discrete trigger events can predict (a rise in) hate crimes in a community (Borell, 2015; King \& Sutton, 2013). For example, Devine (2020) reported an increase in race and religious hate crimes in England and Wales following the Brexit referendum in 2016. Anti-Arab and anti-Muslim hate crimes in the United States surged after the 9/11 terror attacks, namely, in counties with larger Arab and Muslim populations (Byers \& Jones, 2007; Disha et al., 2011; Swahn et al., 2003). Similar victimization patterns were observed in the UK following 9/11 and the 7/7 London bombings (Hanes \& Machin, 2014; Sheridan, 2006; Sheridan \& Gillet, 2005). Notably, a significant increase in anti-Muslim hate crimes was documented one year on from the 7/7 attacks (Hanes \& Machin, 2014), although other research points to rather immediate, short-term implications of trigger events on hate crimes (Devine, 2020; King \& Sutton, 2013). Trigger events also appear to affect hate crime victimization beyond the location where the discrete event took place. Jihadi-inspired terror attacks worldwide predicted a rise in anti-Muslim hate crimes in Manchester, with a spike two to three days after the respective attack (Ivandic et al., 2019; see as well Böhmelt et al., 2020; Legewie, 2013).

To explain why discrete events are associated with an increase in hate crime victimization, it is helpful to understand the offences as a form of vicarious retribution $\underline{1}$ (Lickel et al., 2006). A trigger event, such as a terror attack, highlights that the ingroup has been (or could be) harmed. The trigger event could evoke new perceived threats, bring attention to existing sentiments, or both. The event also suggests who ought to be held responsible for the (perceived) threat (e.g., extremist/terrorist group). Attribution of responsibility is often informed by media reporting (Gentzkow \& Shapiro, 2004; Ivandic et al., 2019); it does not require objective proof (King \& Sutton, 2013). Importantly, responsibility for (potential) ingroup harm is frequently generalized from the specific actors leading the event to the wider social group that these actors claim or are thought to represent. For instance, Muslim residents in European countries are held responsible for the threat posed by jihadi-inspired terrorist groups. Based on the generalization of responsibility, violence against 
individuals who were not involved in the discrete event but who appear to belong to the threatening outgroup (i.e., vicarious retribution; Lickel et al., 2006) is considered justified to achieve justice on behalf of the ingroup. In other words, the trigger event and, specifically, its interpretation as an ingroup threat raises the need and provides legitimization for hate crimes. Moreover, vicarious retribution is to be expected as soon as, and for as long as the outgroup is perceived as threatening; this may explain inconsistent findings with respect to the period after which trigger effects can be observed (i.e., Davies, 2020; Hanes \& Machin, 2014; King \& Sutton, 2013).

\section{The COVID-19 Outbreak, Sinophobic Attitudes, and Hate Crimes}

After the COVID-19 outbreak in early 2020, evidence for generalized attribution of responsibility and vicarious retribution that targeted individuals of Chinese or East Asian descent emerged. Disinformation campaigns, suggesting a strategic spread of the virus by Chinese authorities, were widely circulated on social media platforms (ISD, 2020a; ISD, 2020b). Expressions of negative attitudes and hate towards China and Chinese persons followed suit. Analyzing English-language Twitter data between January and March 2020, Stechemesser, Wenz, and Levermann (2020) showed that hateful, sinophobic language increased after the first person died with COVID-19 in China. As China introduced strict measures to curb the pandemic, incidents of hateful language resided, only to increase again as COVID-19 spread globally. Similar trends were observed on 4chan's Politically Incorrect board; here, racial slurs were more frequently used than on Twitter and a significant peak was identified after Donald Trump labelled COVID-19 the 'China virus' (Schild et al., 2020). A survey study of the Chinese diaspora further showed that $25.1 \%$ of respondents experienced a form of discrimination and stigmatization after the COVID-19 outbreak (He et al., 2020). These 'mere' statistics were echoed in accounts of the personal experiences of individuals of Chinese or East Asian descent, who reported numerous incidents of physical and verbal assault during the pandemic (Gover et al., 2020; Jeung \& Nham, 2020; Tessler et al., 2020).

Taken together, the aforementioned findings suggest that the COVID-19 pandemic served as a trigger event, associated with an increase in sinophobic hate crimes. However, some limitations of the studies and data must be acknowledged. Firstly, expressions of derogatory language that were analyzed on social media (e.g., search word combinations such as: Chinese AND disgusting, Chinese AND Corona AND hate, Chinese AND Corona AND dirty; Stechemesser et al., 2020) are likely inaccurate estimates of the prevalence of online hate speech, which itself only constitutes one 
type of hate crime (in some countries). On the one hand, the number of keywords that identify hateful or intimidating language are, understandably, limited. On the other hand, due to the automated analysis of large datasets, it cannot be guaranteed that each data point represents an incident of hate speech or a unique incident. Furthermore, reports of discrimination and stigmatization may overestimate hate crime victimization (He et al., 2020) as these sentiments can be, but are not necessarily, evoked by hate crimes. Finally, although descriptions of personal experiences offer deep insights into the manifestation of sinophobic hate crimes, they do not allow for an analysis of broader trends over time.

\section{The Present Research}

To address these challenges and extend previous research, we conducted two studies, both focused on the United Kingdom. Relying on police-recorded race hate crime data from London over a period of 12 months (Study 1), and a victimization survey completed by members of different ethnic minority groups resident in the UK (Study 2), we investigated whether the COVID-19 outbreak in the UK was associated with an increase in sinophobic hate crimes. We conceptualized the potential effects of the trigger event in two distinct ways. In line with work that examined the influence of terror attacks (e.g., Devine, 2020; Disha et al., 2011; Hanes \& Machin, 2014; Sheridan, 2006), we compared the overall frequency and likelihood of (novel) victimization before and after the discrete event. Additionally, we assessed evidence for targeted hate crime victimization, that is, the extent to which individuals of Chinese or East Asian descent were more likely to be victimized than members of other ethnic minority groups after the COVID-19 outbreak. Lastly, we explored how soon, and for how long after the first novel corona virus case was reported in the UK, patterns of increased and targeted sinophobic hate crime victimization could be identified.

We pursued the aforementioned research question while acknowledging the implications of the first national lockdown in the UK. As fewer people - potential offenders and victims - were present in public spaces during the lockdown, opportunities for offending in these settings might have been reduced (Cohen \& Felson, 1976; Tewksbury et al., 1999). That is, hate crime victimization could have been attenuated. Conversely, it may be speculated that because people spent more time at home, they used the internet more frequently. Increased use of the internet as well as social media for interaction have been found to predict a higher likelihood of being a victim of online stalking or harassment (Bossler et al., 2012; Henson et al., 2013; Marcum, 2008; Ybarra et al., 2011). It is therefore possible that during 
lockdown, a displacement - rather than a reduction in hate crime victimization - to online settings was observed.

Our research is relevant for several reasons. Current measures to prevent hate crimes prioritize law enforcement training, community partnerships, youth education, promoting hate crime reporting, and hot spot policing in areas where hate crimes frequently occur (e.g., Hampshire Police and Crime Commissioner, 2017; Home Office, 2016; 2018a; MOPAC, 2017; Safer Stronger Doncaster, 2017). However, few policies acknowledge that local, national and international events may increase the risk for hate crimes at certain points in time (see, however, Freilich \& Chermack, 2013; Tell MAMA, 2018; Tony Blair Institute for Global Change, 2019). By strengthening the empirical evidence on trigger events - demonstrating its implications as well as when, and for how long, these are to be expected - we aim to attract the attention of policy makers and practitioners to extend existing hate crime prevention strategies.

We further seek to advance the conceptual understanding of trigger events. Terror attacks are the most commonly assessed trigger event (see Devine, 2020, for an exception). We analyze an event type that is markedly different. Following a terror attack, its consequences for the ingroup are immediately clear. In the case of unfamiliar events such as a global pandemic, an understanding of the threat first needs to be established, which could provoke a delayed manifestation of the trigger effect. Additionally, the duration of terror attacks is relatively short; the event is temporary compared to a global pandemic. Our analyses thus offer insights to determine whether discrete events for which the full extent of the ingroup threat only emerges over time are also associated with an immediate (rather than delayed) increase in hate crime victimization, as well as if a rise in hate crime counts prevails (or is temporary) for long-lasting discrete events (Devine, 2020; King \& Sutton, 2013). Lastly, we take a comparative approach to identify similarities and differences in hate crime victimization between ethnic groups (University of Sussex and Demos, 2018). Doing so, we can conclude whether trigger effects are generalized (i.e., against all "others") or indeed targeted at particular ethnic minorities (i.e., against those who are perceived as a specific threat). The results also contribute to a better understanding of hate crime victimization of individuals of Chinese and East Asian descent who, despite harmful assumptions of a 'model minority' (Berdahl \& Min, 2012; Rappleye, 2018; Abrams, 2019) as well as gendered racism of effeminate males and exoticized women (Hall et al., 2015; Mukkamala \& Suyemoto, 2018), are less frequently considered in hate crime research. 


\section{Study 1: Analyses of Police-recorded Race Hate Crime Count in London}

The first study aimed to examine the immediate as well as long-term implications of the COVID-19 outbreak on hate crime victimization of different minority groups in London. We focused on a study period between July 2019 and July 2020 to capture six months before and after the COVID-19 outbreak in the UK. $\underline{2}$ Key events of the so-called first wave of the pandemic fall within the time frame. The first COVID-19 case was documented in the UK on January 31st 2020. The government announced first national lockdown measures on March 23rd, which were imposed as of March 26th. On May 13th, lockdown measures were partially lifted; more outdoor activities were allowed, and non-essential shops were opened. Further restrictions were eased in the following weeks.

In Study 1, we relied on publicly available police-recorded hate crime data from the London Metropolitan Police special crime dashboard. Given the limited categories of hate crime that are available through this service, sinophobic hate crime was operationalized as race hate crime, that is, criminal offences driven by bias towards the victim's race, nationality, ethnic or national origin. We investigated whether and how police-recorded race hate crime counts changed between July 2019 and July 2020 (Research Question 1). Evidence for a trigger effect of the pandemic would be provided if an increase in race crime count were observed after January 2020. We further assessed if and how the trend for race hate crime count differed from that of anti-Semitic, Islamophobic, and faith hate crime (Research Question 2). Doing so, we explored patterns of targeted - rather than only an overall increase in - hate crime victimization.

\section{Data}

The Metropolitan Police hate crime and special crime dashboard provides aggregated data for monthly 'racist and religious hate crime' counts (Metropolitan Police, 2021). This data summarizes race, anti-Semitic, Islamophobic, and faith hate crimes. Separate data is only available for the latter three categories. Consequently, race hate crime can be calculated by subtracting anti-Semitic, Islamophobic, and faith hate crime from 'racist and religious hate crime'. The analysis below is based on these four time-series, consisting of monthly crime counts from July 2019 to July 2020 (Table 1).

- Table 1 here-

\section{Analytical Approach}


All analyses were completed with $R$ 3.6.2. The study pre-registration and analysis script, including the data, are available online $\underline{3}$. To analyze possible changes in race hate crime count as well as the targeted victimization of individuals based on their ethnicity or race, we explored the data structure that underlies each time-series (i.e., race, anti-Semitic, Islamophobic, and faith hate crime counts over 12 months). We compared the fit, or smallest discrepancy from the observed data, of two non-nested models (see Kleinberg et al., 2020). Specifically, we modelled an intercept-only model with a regression coefficient set at zero that predicted no change in hate crime count as well as a structural breakpoint model with $n$ structural breaks, at which the nonzero regression coefficient changes. For the latter model, the number of breaks was not pre-defined but identified by relying on Bayesian Information Criterion (BIC) plots. The timing of the breaks and direction of change were extracted by plotting the breakpoint model on the observed data (Zeileis et al., 2003). Akaike's Information Criterion (AIC; Akaike, 1974), BIC, as well as the mean absolute error (MAE) and the root mean squared error (RMSE) were computed for all models. Better model fit was indicated by lower AIC, BIC, MAE, and RMSE values.

If hate crimes against Chinese or East Asian persons had increased after the COVID-19 outbreak in the UK, it would be expected that a breakpoint model with at least one breakpoint after January 2020 - at which crime count increased - would fit the data for race hate crime better than the intercept-only model. If the pandemic was associated with a higher risk of targeted victimization of Chinese or East Asian persons, timeseries of anti-Semitic, Islamophobic, and faith hate crime should not be described by the same breakpoint model as race hate crime.

\section{Results and Discussion}

For race hate crime counts, the breakpoint model with one structural break in May 2020 fitted the observed data best (Table 2; Figure 1, panel A). From May to June 2020 , race hate crime count increased significantly. The structural breakpoint model with one breakpoint in January 2020 provided the best model fit for anti-Semitic hate crime count (Table 2; Figure 1, panel B). In January 2020, anti-Semitic hate crime count decreased significantly. The observed data for faith hate crime was best described by a structural breakpoint model with two breaks in February and April 2020 (Table 2; Figure 1, panel C). In February, before lockdown measures were introduced, faith hate crime was reduced only to increase again in April 2020. Comparing model fit indices, a breakpoint model with one structural break fitted the 
Islamophobic hate crime data best (Table 2; Figure 1, panel D): in February 2020, Islamophobic hate crime decreased significantly.

-Table 2 here-

-Figure 1 here-

Taken together, Study 1 showed that race hate crimes increased after the COVID-19 outbreak in the UK. We further found tentative evidence for targeted victimization on grounds of race and ethnicity after the start of the pandemic, as religious hate crime counts were not described by the same trend. An increase in race hate crime from May to June 2020 might be indicative of a delayed manifestation of a trigger effect four months after the discrete event. Indeed, a public opinion poll revealed that at this time more than $60 \%$ of respondents believed that the pandemic posed a very high or high threat to their country (compared to $20 \%$ in early February/March; Ipsos MORI, 2020). Thus, it may be speculated that the trigger event manifested itself once perceptions of ingroup threat were established and reached a certain threshold.

However, one could also argue that national lockdown measures delayed the expression of the trigger event; it was only captured after restrictions were lifted in May 2020 and opportunities for offending were increased. Contesting this conjecture, no change in race hate crime count was documented before lockdown, in February and March 2020 (King \& Sutton, 2013). Additionally, faith hate crime count increased while lockdown measures were in force. Overall, lockdown measures appear to have had no systematic effect on victimization patterns.

Finally, we must acknowledge that the documented rise in race hate crime count may reflect another trigger event. Namely, at the end of May 2020, protests erupted around the world, including in London, in response to the killing of George Floyd in the United States. The Black Lives Matter (BLM) movement gained traction in the next weeks, with a protest in London on 6 June attracting approximately 20000 attendants. Protest activity continued throughout June 2020 in different cities in the UK. It is possible that the BLM protests were interpreted as a threat by White British persons, such that hate crimes against individuals of African, Caribbean, and Black British descent increased.

More detailed analyses are needed to specify these conclusions and speculations. Crucially, a broad range of victims were reflected in the race hate crime data. Following guidance by the UK College of Policing, "Race means any group defined by race, colour, nationality or ethnic or national origin, including countries within the UK, 
and Gypsy or Irish Travellers." (2014). Similarly, in official statistics by the UK Home Office, ethnicities tend to be grouped under broad categories - 'White', 'Asian', 'Black', 'Mixed', and 'Other' (Home Office 2018b; 2020) - which does not allow for a nuanced understanding of the East Asian community. It is therefore very likely that unique rapidly changing - trends pertaining only to individuals who describe their ethnicity as East Asian were masked by patterns of victimization that affected different ethnic and racial groups. As discussed earlier, it also cannot be ruled out that the observed trend does not at all refer to the hate crimes/incidents experienced by Chinese/East Asian persons. Finally, police-recorded crime data may, overall, severely underestimate the implications of the COVID-19 outbreak as these records are affected by reporting biases. Notably, hate crime victims often do not report their victimization due to concerns of retaliation or distrust in the police (Pezzella et al., 2019).

\section{Study 2: Victimization Survey}

To address the limitations and further specify the conclusions of Study 1, we conducted a victimization survey. The sample included participants who describe their ethnicity as Chinese or East Asian as well as members of other ethnic minority groups, all resident in the UK. Study 2 assessed hate crime/incident victimization before the pandemic and between February and the end of May 2020. This latter time frame was chosen to capture immediate as well as medium-term implications of the COVID-19 outbreak. In addition, the study period does not include the Black Lives Matter protests (discussed in Study 1).

We investigated whether individuals of Chinese or East Asian descent experienced between February and the end of May 2020 more frequent victimization or an increased likelihood in novel hate crime victimization, compared to before the COVID19 outbreak in the UK (Hypothesis 1). Furthermore, we examined if after the COVID19 outbreak, Chinese and East Asian persons were more likely to be targeted, that is, had a higher likelihood of hate crime victimization than members of other ethnic minority groups (Hypothesis 2). Exploratory analyses that had not been pre-registered sought to identify when, and for how long after the first COVID-19 case was reported in the UK, increased or targeted sinophobic hate crime victimization could be identified (Research Question 1).

Study 1 had not pointed to clear attenuating effects of national lockdown measures. It is possible, however, that this observation was due to the fact that the lockdown fostered a displacement of hate crimes to online spaces that could be easily - and more frequently - accessed by potential victims and perpetrators. In Study 2, we examined 
the settings of reported hate crimes to understand the extent to which crimes that occurred between February and March 2020 were less likely to take place online than crimes reported during the lockdown (Hypothesis 3).

\section{Method}

Ethical approval for this study was granted by the IRB board of the authors' institution. Participants did not give consent to share the data with third parties. The pre-registration and material of the study, however, are available online $\underline{4}$.

Design and Sample. This cross-sectional survey was completed by $N=393$ participants; $\mathrm{n}=200$ participants described themselves as being of Chinese or East Asian descent and $\mathrm{n}=193$ participants reported another, non-White ethnicity $\underline{5}$. Sample size was restricted by the available resources. A sensitivity analysis highlighted that given $\alpha=.05$, power $=.95$, and the respective group sizes, at least moderate $(\mathrm{d}=.33)$ between-group and small $(\mathrm{dz}=.22)$ within-group differences could be identified. Plotting the sensitivity analyses (Supplementary material, Figure S1-S2), it is evident that for very small effects approximately $50 \%$ power could be achieved.

Participants were on average $30.4(S D=10.3)$ years old; $57.3 \%$ stated their gender as female, $42.2 \%$ as male, one person reported being non-binary and one person preferred not to report their gender. The majority of participants had a university degree (69.6\%), followed by those who had completed their A-levels or equivalent degrees (22.2\%). Only 1.3\% had not finished school and 6.9\% completed compulsory schooling. All participants lived in the UK at the time of data collection.

Measures. In the UK, bias motivation of a crime is confirmed by drawing on the perception of the victim or a bystander (Crown Prosecution Service, 2020). In line with this rationale, participants reported whether, since 1 February 2020, they had experienced hateful comments and behavior they believed were motivated by the offenders' negative attitudes towards their ethnicity, race, or nationality (i.e., hate crime/incident victimization). Participants further indicated how many times they had been victimized since 1 February 2020. Subsequently, more detailed information about the crime(s) or incident(s) was assessed. Further to stating when the crime/incident had occurred (February 2020 (before lockdown), 1.-23.3.2020 (before lockdown), 24.3.-13.5. (during lockdown), since 14.5.2020 (after lockdown)), participants were asked whether they had reported the crime/incident to the police and where it had happened (on the street, near home, commercial setting, on public transport, at school 
or college, in parking lot, at home, online: social media in public setting, online: social media in private setting or email, online: comment section of news).

We then examined the specific type of offence: 'verbal harassment', 'assault with injury', 'assault without injury', 'robbery', 'household crime' and 'none of the above but I felt uncomfortable', were possible answer options (multiple answers were possible). All but the last classification are considered criminal offences, hate crimes. Experiences that made participants uncomfortable are, going forward, referred to as hate incidents (Crown Prosecution Service, 2020). Lastly, we assessed whether participants knew the perpetrator, if a bystander intervened and, if so, whether they knew the bystander. The aforementioned information could be provided for up to five crimes/incidents. To complete the survey, participants then reported if they had been a victim of hate crimes or incidents before February 2020, and, if so, how many crimes/incidents they had experienced. Information about police-reporting, location, type of hate crime/incident, knowledge of perpetrator and bystander intervention were also stated for the past incidents.

Procedure. Participants were invited through the online opt-in access panel Prolific Academic. Participation was initially restricted to panel members who describe their ethnicity as East Asian. After the target sample size of $n=200$ was attained, the survey was opened to panel members who reported another, non-White ethnicity. Participants completed the questions in their own time and received 1.10 GBP upon finishing the study. The study was conducted in the last week of May 2020.

\section{Results and Discussion}

Descriptive Results. Overall, $n=134$ participants stated that they had been a hate crime/incident victim since February 2020; $n=259$ participants had not been victimized. In the study period, one case of victimization was the most common (53\%), followed by three (17\%), or two (14\%) hate crime/incidents. A total of 327 crimes/incidents were experienced. Table 3 shows information about the crimes/incidents. In addition to overall data, information for participants of Chinese or East Asian descent and other participants is presented separately. It should be noted again that participants were only able to report details about up to five crimes/incidents. Table 3 is therefore only based on reports of 287 hate crimes/incidents; 182 of these were reported by Chinese/East Asian persons.

The most common crime type, for all participants regardless their ethnicity, was verbal harassment (see as well Allen \& Nielsen, 2002; Table 3). Hate crimes and incidents 
occurred most frequently 'on the street', in commercial settings, or on public transport (Table 3). More cases of victimization were reported in the months before as compared to during the national lockdown. For only eight crimes/incidents, victimization was reported to the police. The perpetrator was known to the victim for 12 crimes/incidents. Bystanders intervened in 43 crimes/incidents.

-Table 3 here-

Before February 2020, $\mathrm{n}=216$ participants were victims of one or more hate crimes/incidents; $\mathrm{n}=176$ had not been victimized. The majority, $\mathrm{n}=203$ participants, of those victimized had not reported any of the crimes or incidents to the police; $\mathrm{n}=$ 173 did not know the perpetrator; $n=177$ were not supported by bystanders. Table 4 documents more detailed information about the 265 hate crimes/incidents that participants experienced before February 2020, 129 of those were reported in the survey by persons of Chinese or East Asian descent.

-Table 4 here-

\section{The COVID-19 outbreak as a trigger event for sinophobic hate crimes.}

Considering only the sub-sample of $n=200$ participants who described their ethnicity as Chinese or Other East Asian, 46\% $(n=91)$ reported that that they had been a hate crime/incident victim since the COVID-19 outbreak. There was no evidence that participants who had never been victimized in the past were more likely to be victimized after the outbreak $\left(\chi^{2}(1)=.368, p=.544, \operatorname{logOR}=.172\right.$, OR $\left.=1.19\right)$. Participants of Chinese or East Asian descent also experienced on average more crimes or incidents before $(M=4.51, S D=16.08)$ as compared to after the outbreak $(M=1.08, S D=2.37 ; t(199)=-3.02, p=.003, \mathrm{~d}=-.21)$. This latter result is perhaps not surprising, given that the period referring to 'before the outbreak' included participants' whole life. Focusing only on an increase in the frequency over time or likelihood of novel victimization, we cannot support that the COVID-19 outbreak elicited more sinophobic hate crime/incident victimization for Chinese or East Asian persons in our sample.

We then examined if participants of Chinese or East Asian descent were more likely to be victimized than participants from other ethnic minority groups after the first COVID19 case was reported in the UK. This analytical approach does not capture changes in victimization over time but assesses patterns of targeted victimization of a specific social group that would be expected based on the nature of the trigger event. Chinese/East Asian persons represented 68\% of the participants who were victimized 
after the COVID-19 outbreak; they were OR $=2.97$ times more likely to be a hate crime/incident victim than members of other ethnic minority groups, $\chi^{2}(1)=23.57, p$ $<.001, \log \mathrm{OR}=1.07$. Before February 2020, the likelihood of victimization did not differ between individuals of Chinese/East Asian descent and members of other ethnic minority groups $\left(\chi^{2}(1)=2.14, p=.143, \log \mathrm{OR}=-.30, \mathrm{OR}=1.12\right)$. That is, we demonstrated evidence for the targeted victimization of Chinese and East Asian persons after the COVID-19 outbreak.

Next, we explored when precisely the risk of targeted victimization was higher for Chinese/East Asian participants. We considered the $n=287$ crimes/incidents for which detailed information about the timing was available. In February, Chinese/East Asian participants were $\mathrm{OR}=2.32$ times more likely to be victimized than other participants $\left(\chi^{2}(1)=4.54, p=.033, \operatorname{logOR}=.84\right)$. In March $\left(\chi^{2}(1)=.67, p=.414, \log \mathrm{OR}=.24, \mathrm{OR}\right.$ $=1.27$ ) and during lockdown $\left(\chi^{2}(1)=.28, p=.594\right.$, $\log \mathrm{OR}=-.16$, OR $=.85$ ) no differences in the likelihood of victimization were identified. After lockdown was eased in mid-May (with data collection completed in the last week of May), participants who described their ethnicity as South Asian, African, Caribbean, or Black British had actually a higher likelihood of hate crime victimization $\left(\chi^{2}(1)=9.77, p=.002, \log \mathrm{OR}=\right.$ 1.26, OR = 3.54). This latter finding may reflect the impact of the Black Lives Matter protests that were discussed in Study 1.

Displacement online. Finally, we assessed settings of hate crime/incidents after the COVID-19 outbreak. As indicated in Table 3, overall, only about $15 \%$ of crimes/incidents were reported to have occurred online. While lockdown was in place, only three (out of $n=55$ ) reported crimes/incidents occurred online. No further inferential statistical analyses were computed. There was no evidence for the online displacement of hate crime.

In summary, we did not find that the COVID-19 outbreak facilitated more frequent or novel victimization of individuals of Chinese or East Asian descent. The trigger effect of the pandemic was, however, manifested in the targeted victimization of Chinese or East Asian persons who were more likely to be a hate crime/incident victim than members of other ethnic minority groups after (but not before) the COVID-19 outbreak. In line with previous research (Devine, 2020; King \& Sutton, 2013), the targeted victimization of Chinese/East Asians persons was documented immediately after the discrete event started, in February 2020. This finding suggests that even though threat perceptions were further strengthened after March 2020 (Ipsos Mori, 
2020) and the pandemic continued, patterns of hate crime victimization changed rapidly.

Having said this, the following limitations impact the data quality and conclusions. Firstly, selection effects mean that the survey may have attracted participants who were willing to share their experiences or were willing to share specific incidents. The overall level of past and current victimization therefore could be overestimated, which may explain discrepancies with He et al.'s (2020) research (i.e., 25\% of their Chinese participants reported victimization as compared to $46 \%$ in our study). Equally, if participants don't feel comfortable speaking about more severe crimes - rather than verbal harassment, which was the most common crime type - victimization may be underestimated (Iwama, 2018). Moreover, findings should not be generalized to the whole population of ethnic minority groups resident in the UK. The sample was overall highly educated, and this may affect (higher) willingness to complete the study as well as victimization experiences. The study also focused on a limited period after the COVID-19 outbreak. It is possible that following repeated lockdowns and more information about the true impact of the pandemic, victimization of Chinese/East Asian persons increased even more. We therefore recommend that future research aims to replicate our results, capturing a longer period. Of course, whenever research relies on the recollection of past events, it is possible that not all information is remembered accurately, which may affect the accuracy of our data as well (in particular reports of victimization before the pandemic).

\section{General Discussion}

COVID-19 has impacted people's lives worldwide in multiple ways. Here, we examined whether the outbreak of the novel corona virus was associated with a rise in sinophobic hate crime victimization. Focusing on the United Kingdom, our results partially confirmed the proposed trigger effect of the pandemic. The strongest evidence was provided by findings of a victimization survey: individuals who described their ethnicity as Chinese or East Asian were, compared to members of other ethnic minority groups, more likely to be hate crime/incident victims in the month after the first COVID-19 case was reported in the UK.

Our research has important implications for theory and practice. Firstly, we lend further support to the literature on trigger events (e.g., Borell, 2015; Byers \& Jones, 2007; Disha et al., 2011; King \& Sutton, 2013; Swahn et al., 2003). We confirm that trigger events can predict distinct patterns of hate crime victimization especially in the period shortly after the discrete event, even in cases where the full consequences 
cannot yet be anticipated, or the event is lasting. Those who design law enforcement training and hate crime prevention strategies should take note of these insights to prepare responses in the wake of critical events that could be perceived as an ingroup threat. Relatedly, we suggest extending current hate crime offender typologies (e.g., McDevitt et al., 2002) to generalize the category of retaliatory hate crime to include activities that are reactions to a wide range of events, not only hate crimes targeting the ingroup.

Unfortunately, we cannot specify the underlying processes of the observed results. Data from a public opinion poll suggests that in February 2020 only a small proportion of British citizens considered the novel corona virus as a severe threat to their country, yet targeted victimization of Chinese/East Asian persons was documented. We may speculate that this suggests that even low levels of perceived threat can initiate trigger effects. However, to confirm this hypothesis, future research must investigate more explicitly how trigger events shape hate crime victimization; experimental studies seem most suitable and would allow for causal conclusions that can inform hate crime prevention measures.

Study 2 showed that a comparative approach that considers patterns of targeted victimization is valuable when studying trigger events. We found that the COVID-19 outbreak was associated with the increased likelihood of victimization of participants of Chinese or East Asian descent. However, at the end of May 2020 this pattern was reversed; members of other ethnic minority groups were more likely to be hate crime/incident victims. Only the survey study allowed us to draw these nuanced conclusions as the police-recorded hate crime data was aggregated at a higher level, representing members of different ethnic and racial groups. Official statistics from the UK Home Office also present only broad categories, such as 'Asian', that do not afford detailed analyses (Home Office, 2018b; 2020). In order to identify and address hate crimes against the Chinese/East Asian community, data must be collected and made available at a more granular level. The need for this - the effective prevention of antiEast Asian hate in the UK - is clearly evident. We demonstrated that before the COVID19 outbreak in the UK, the likelihood of hate crime/incident victimization of individuals of Chinese and East Asian descent did not differ from that of members of other ethnic minority groups. A study by The Monitoring Group (Adamson et al., 2009) found as well substantial levels of sinophobic verbal and physical abuse in three British cities.

Finally, we want to note that Study 2 showed that the majority of hate crimes and incidents - before and after the COVID-19 outbreak - did not occur online. The result is 
in line with research by Jeung and Nham (2020) who examined the experiences of East Asian-Americans during the COVID-19 pandemic. The observation suggests that when studying and aiming to counter hate crime, online settings should not receive more attention than victimization in public spaces offline: most hate crimes/incidents were reported on the street or on public transport. Having said this, it is possible that acts of hate speech online are less likely to be considered disturbing, or a criminal offence, than verbal harassment 'offline' and therefore go unreported (Baumgarten et al., 2019; Costello et al., 2019). This discord affects the specification of the true rate of hate crime victimization as well as the ability to detect trigger events. Future research should therefore explore victim's perceptions of victimization across different settings.

\section{Conclusion}

Taken together, we showed that the COVID-19 outbreak in the United Kingdom served as a trigger event that increased the targeted hate crime victimization of Chinese and East Asian persons, especially in the month after the start of the pandemic. The results strengthen previous evidence and enforce the message that hate crime prevention ought to consider when victimization is most likely to occur. Additionally, we document that hate crime data must record victim's ethnicity at a more granular level to improve responses to hate crimes against specific communities.

\section{References}

Abrams, Z. (2019). 'Countering stereotypes about Asian Americas', American Psychological Association, 50(11). [Online] Available at: https://www.apa.org/monitor/2019/12/countering-stereoty.pes (Accessed: 04 March 2021).

Adamson, S., Cole, B., Craig, G., Hussain, B., Smith, L., Law, I., ... \& Cheung, T. (2009). Hidden from public view? Racism against the UK Chinese population. London: The Monitoring Group/DCLG.

ADL (2020). Reports of Anti-Asian Assaults, Harassment and Hate Crimes Rise as Coronavirus Spreads. [Online]. Available at: https://www.adl.org/blog/reports-of-antiasian-assaults-harassment-and-hate-crimes-rise-as-coronavirus-spreads (Accessed: 04 March 2021).

Akaike, H. (1974). A new look at the statistical model identification. IEEE transactions on automatic control, 19(6), 716-723. https://doi.org/10.1109/TAC.1974.1100705 
Allen, C., \& Nielsen, J. S. (2002). Islamophobia in the EU after 11 September 2001: Summary report. Diane Publishing Company.

Baumgarten, N., Bick, E., Geyer, K., Kleene, A., Lund Iversen, D., Lindø, A. V., Neitsch, J., Niebuhr, O., Nielsen, R. \& Petersen, E. N. (2019). Towards balance and boundaries in public discourse: Expressing and perceiving online hate speech (XPEROHS). RASK: International Journal of Language and Communication. [Online]. Available at: http://eprints.whiterose.ac.uk/154578/8/RASK_author_accepted_manuscript.pdf (Accessed 04 Mach 2021).

BBC (2020). Coronavirus: Men wanted over racist Oxford Street attack on student, 4 March 2020 [Online]. Available at: https://www.bbc.co.uk/news/uk-england-london$\underline{51736755}$ (Accessed 04 Mach 2021).

Berdahl, J. L., \& Min, J. A. (2012). Prescriptive stereotypes and workplace consequences for East Asians in North America. Cultural Diversity and Ethnic Minority Psychology, 18(2), 141-152. https://doi.org/10.1037/a0027692.

Böhmelt, T., Bove, V., \& Nussio, E. (2020). Can terrorism abroad influence migration attitudes at home?. American Journal of Political Science, 64(3), 437-451. https://doi.org/10.1111/ajps.12494

Bossler, A. M., Holt, T. J., \& May, D. C. (2012). Predicting online harassment victimization among a juvenile population. Youth \& Society, 44(4), 500-523. https://doi.org/10.1177/0044118X11407525

Borell, K. (2015). When is the time to hate? A research review on the impact of dramatic events on Islamophobia and Islamophobic hate crimes in Europe. Islam and Christian-Muslim Relations, 26(4), 409-421. https://doi.org/10.1080/09596410.2015.1067063

Byers, B. D., \& Jones, J. A. (2007). The impact of the terrorist attacks of 9/11 on antiIslamic hate crime. Journal of Ethnicity in Criminal Justice, 5(1), 43-56. https://doi.org/10.1300/J222v05n01_03

Cohen, L. E., \& Felson, M. (1979). Social change and crime rate trends: A routine activity approach. American Sociological Review, 44(4), 588-608. https://doi.org/10.2307/2094589

Costello, M., Hawdon, J., Bernatzky, C., Mendes, K. (2019). Social Group Identity and Perceptions of Online Hate, Sociological Inquiry, 89(3), pp. 427-452 [Online]. Available 
at: https://onlinelibrary.wiley.com/doi/abs/10.1111/soin.12274.

Crown Prosecution Service (2020). Hate Crime. Available https://www.cps.gov.uk/crimeinfo/hate-crime (Accessed 04 Mach 2021).

Devine, D. (2020). Discrete Events and Hate Crimes: The Causal Role of the Brexit Referendum. Social Science Quarterly. 102: 374-386.

https://doi.org/10.1111/ssqu.12896

Disha, I., Cavendish, J. C., \& King, R. D. (2011). Historical events and spaces of hate: Hate crimes against Arabs and Muslims in post-9/11 America. Social Problems, 58(1), 21-46. https://doi.org/10.1525/sp.2011.58.1.21

Gentzkow, M. A., \& Shapiro, J. M. (2004). Media, education and anti-Americanism in the Muslim world. Journal of Economic Perspectives, 18(3),117-133. https://doi.org/10.1257/0895330042162313

Gover, A. R., Harper, S. B., \& Langton, L. (2020). Anti-Asian hate crime during the COVID-19 pandemic: Exploring the reproduction of inequality. American Journal of Criminal Justice, 45(4), 647-667. https://link.springer.com/article/10.1007/s12103-020$\underline{09545-1}$

Green, D. P., McFalls, L. H., \& Smith, J. K. (2001). Hate crime: An emergent research agenda. Annual Review of Sociology, 27(1), 479-504. https://doi.org/10.1146

Hall, V. E., Galinsky, D. A., Phillips, W. K. (2015). Gender Profiling: A gendered race perspective on person-position fit, Personality and Social Psychology Bulletin, 14(6), pp.853-868 [Online]. Available at:

https://journals.sagepub.com/doi/10.1177/0146167215580779 (Accessed $4^{\text {th }}$ March 2021).

Hampshire Police and Crime Commissioner (2017). Hate Crime Strategy 2017-2021. [Online]. Available at: https://www.hampshire-pcc.gov.uk/wpcontent/uploads/2018/04/Hate-Crime-Strategy-2017-2021-Appendix-Onev2.pdf (Accessed $4^{\text {th }}$ March 2020).

Hanes, E., \& Machin, S. (2014). Hate crime in the wake of terror attacks: Evidence from 7/7 and 9/11. Journal of Contemporary Criminal Justice, 30(3), 247-267. https://doi.org/10.1177/1043986214536665 
He, J., He, L., Zhou, W., Nie, X., \& He, M. (2020). Discrimination and social exclusion in the Outbreak of COVID-19. International Journal of Environmental Research and Public Health, 17(8), 2933. https://doi.org/10.3390/ijerph17082933

Henson, B., Reyns, B. W., \& Fisher, B. S. (2013). Fear of crime online? Examining the effect of risk, previous victimization, and exposure on fear of online interpersonal victimization. Journal of Contemporary Criminal Justice, 29(4), 475-497. https://doi.org/10.1177/1043986213507403

Home Office (2016). Action Against Hate, The UK Government's Plan for Tackling Hate Crime. (ISBN 978-1-78655-163-4) Home Office. Available at:

https://assets.publishing.service.gov.uk/government/uploads/system/uploads/attachmen t data/file/927673/2016 Hate Crime Action Plan.pdf (Accessed $4^{\text {th }}$ March 2021).

Home Office (2018a). Action Against Hate, The UK Government's Plan for Tackling Hate Crime- 'two years on'. Home Office.

https://assets.publishing.service.gov.uk/government/uploads/system/uploads/attachmen t_data/file/748175/Hate_crime_refresh_2018_FINAL_WEB.PDF (Accessed $4^{\text {th }}$ March 2020).

Home Office (2018b). Hate crime, England and Wales 2017-2018. Home Office. (ISSN 1759-7005). Available at:

https://assets.publishing.service.gov.uk/government/uploads/system/uploads/attachmen t_data/file/748598/hate-crime-1718-hosb2018.pdf (Accessed $4^{\text {th }}$ March 2021).

Home Office (2020). Hate Crime, England and Wales, 2019 to 2020. (ISSN 1759-7005). Home Office. Available at:

https://assets.publishing.service.gov.uk/government/uploads/system/uploads/attachmen t data/file/925968/hate-crime-1920-hosb2920.pdf (Accessed $4^{\text {th }}$ March 2021).

Ipsos MORI (2020). Coronavirus, Tracking UK public perception. Available at: www.ipsos.com/sites/default/files/2020-04/coronavirus-covid-19-infographic-ipsosmori.pdf (Accessed $4^{\text {th }}$ March 2021).

Ivandic, R., Kirchmaier, T., \& Machin, S. J. (2019). Jihadi attacks, media and local hate crime. CEPR Discussion Paper No. DP13743. Available at SSRN: https://ssrn.com/abstract=3395180 (Accessed $4^{\text {th }}$ March 2021). Iwama, J. (2018). Hate crime research in the twenty-first century. R. Martinez, M. Hollis, \& J. Stowell, The Handbook of Race, Ethnicity, Crime, and Justice, 87-103. John 
Wiley \& Sons, Inc.

ISD (2020a). COVID-19 Disinformation Briefing No. 1. Available at:

https://www.isdglobal.org/isd-publications/covid-19-disinformation-briefing-no-1/ (Accessed $4^{\text {th }}$ March 2021).

ISD (2020b). COVID-19 Disinformation Briefing No. 2. Available at:

https://www.isdglobal.org/isd-publications/covid-19-disinformation-briefing-no-2/ (Accessed $4^{\text {th }}$ March 2021).

Jeung, R., \& Nham, K. (2020). Incidents of coronavirus-related discrimination. Available at: https://www.asianpacificpolicyandplanningcouncil.org/wp-content/uploads/ Stop_AAPI_Hate_Weekly_Report_4_3_20.pdf

King, R. D., \& Sutton, G. M. (2013). High times for hate crimes: Explaining the temporal clustering of hate-motivated offending. Criminology, 51(4), 871-894. http://onlinelibrary.wiley.com/doi/10.1111/crim.2011.51.issue-4/issuetoc.

Kleinberg, B., van der Vegt, I., \& Gill, P. (2020). The temporal evolution of a far-right forum. Journal of Computational Social Science, 1-23. https://doi.org/10.1007/s42001$\underline{020-00064-\mathrm{x}}$

Legewie, J. (2013). Terrorist events and attitudes toward immigrants: A natural experiment. American Journal of Sociology, 118(5), 1199-1245.

https://doi.org/10.1086/669605

Lickel, B., Miller, N., Stenstrom, D. M., Denson, T. F., \& Schmader, T. (2006). Vicarious retribution: The role of collective blame in intergroup aggression. Personality and Social Psychology Review, 10(4), 372-390. https://doi.org/10.1207/s15327957pspr1004_6

Marcum, C. D. (2008). Identifying potential factors of adolescent online victimization for high school seniors. International Journal of Cyber Criminology, 2(2), 346-367. [Online]. Available at: http://www.cybercrimejournal.com/catherineijccdec2008.htm /(Accessed $4^{\text {th }}$ March 2021).

McDevitt, J., Levin, J., \& Bennett, S. (2002). Hate crime offenders: An expanded typology. Journal of Social Issues, 58(2), 303-317. https://doi.org/10.1111/1540$\underline{4560.00262}$ 
Metropolitan Police (2021). Hate crime and special crime dashboard. Available at: https://www.met.police.uk/sd/stats-and-data/met/hate-crime-dashboard/ (Accessed $4^{\text {th }}$ March 2021).

MOPAC 2017 (2017). A safer city for all, Londoners Police and Crime Plan 2017-2021. Greater London Authority. Available at: https://www.met.police.uk/SysSiteAssets/foimedia/metropolitanpolice/priorities and how we are doing/corporate/mopac_police crime_plan 2017202 1.pdf (Accessed $4^{\text {th }}$ March 2021).

Mukkamala, S. and Suyemoto, K. L. (2018). Racialized sexism/ sexualized racism: A Multimethod study of intersectional experiences of discrimination for Asian American women, Asian American Journal of Psychology 9(1), pp. 32-46. https://doi.org/10.1037/aap0000104

Murphy, S. (2020). Chinese people in UK targeted with abuse over coronavirus, The Guardian, 18 February [Online]. Available at: https://www.theguardian.com/world/2020/feb/18/chinese-people-uk-targeted-racistabuse-over-coronavirus-southampton

OSCE (2020). What is hate crime. Available at: https://hatecrime.osce.org/what-hatecrime (Accessed $4^{\text {th }}$ March 2021).

Pezzella, F. S., Fetzer, M. D., \& Keller, T. (2019). The dark figure of hate crime underreporting. American Behavioral Scientist. https://doi.org/10.1177/0002764218823844

Rappleye, J. (2018). Stereotypes as Anglo-American Exam Ritual? Comparisons of Students Exam Anxiety in East-Asian, America, Australia and the United Kingdom, Oxford Review of Education, 44(6), pp. 730-754. https://doi.org/10.1080/03054985.2018.1444598

Russell, A. (2020). The rise of coronavirus hate crimes, The New Yorker, 17 March, [Online]. Available at: https://www.newyorker.com/news/letter-from-the-uk/the-rise-ofcoronavirus-hate-crimes (Accessed $4^{\text {th }}$ March 2021).

Safer Stronger Doncaster (2017). Doncaster Hate Crime Strategy 2017-2021 [Online]. Available at https://dmbcwebstolive01.blob.core.windows.net/media/Default/CrimeAntiSocialBehavi- 
ourNuisance/Hate\%20Crime\%20Strategy\%202017-2021.pdf (Accessed $4^{\text {th }}$ March 2021).

Schild, L., Ling, C., Blackburn, J., Stringhini, G., Zhang, Y., \& Zannettou, S. (2020). " Go eat a bat, chang!": An early look on the emergence of sinophobic behavior on web communities in the face of covid-19. arXiv preprint. Available at: https://arxiv.org/abs/2004.04046

Sheridan, L. P. (2006). Islamophobia pre-and post-September 11th, 2001. Journal of Interpersonal Violence, 21(3), 317-336. https://doi.org/10.1177/0886260505282885

Sheridan, L. P., \& Gillett, R. (2005). Major world events and discrimination. Asian Journal of Social Psychology, 8(2), 191-197. https://doi.org/10.1111/j.1467839x.2005.00166.x

Sky News (2020). Coronavirus hate crimes against Chinese people soar in UK during COVID-19 crisis, 5 May [Online]. Available at https://news.sky.com/story/coronavirushate-crimes-against-chinese-people-soar-in-uk-during-covid-19-crisis-11979388 (Accessed 4th March 2021).

Stanko, E.A., 2004. Reviewing the evidence of hate: Lessons from a project under the Home Office Crime Reduction Programme. Criminal Justice, 4(3), pp.277-286. https://doi.org/10.1177/1466802504048466

Stechemesser, A., Wenz, L., \& Levermann, A. (2020). Corona crisis fuels racially profiled hate in social media networks. EClinicalMedicine. https://doi.org/10.1016/j.eclinm.2020.100372

Swahn, M. H., Mahendra, R. R., Paulozzi, L. J., Winston, R. L., Shelley, G. A., Taliano, J., ... \& Saul, J. R. (2003). Violent attacks on Middle Easterners in the United States during the month following the September 11, 2001 terrorist attacks. Injury Prevention, 9(2), 187-189. http://dx.doi.org/10.1136/ip.9.2.187

Tell MAMA (2018). The Importance of Narrative in Responding to Hate Incidents Following 'Trigger' Events [Online]. Available at: https://tellmamauk.org/wpcontent/uploads/resources/Tell\%20MAMA\%20-\%20Report.pdf (Accessed $4^{\text {th }}$ March 20201).

Tessler, H., Choi, M., \& Kao, G. (2020). The Anxiety of Being Asian American: Hate Crimes and Negative Biases During the COVID-19 Pandemic. American Journal of 
Criminal Justice; 45, 636-646. https://doi.org/10.1007/s12103-020-09541-5

Tewksbury, R., Grossi, E. L., Suresh, G., \& Helms, J. (1999). Hate crimes against gay men and lesbian women: A routine activity approach for predicting victimization risk. Humanity \& Society, 23(2), 125-142. https://doi.org/10.1177/016059769902300203

Tony Blair Institute of Global Change (2019). Designing Hate: New Policy Responses to Stop Hate Crime [Online]. https://institute.global/sites/default/files/201908/Hate\%20crime\%20V09B.pdf (Accessed $4^{\text {th }}$ March 2021).

UK College of Policing (2014). National Policing Hate Crime Strategy. Available at: https://www.college.police.uk/What-we-do/Support/Equality/Documents/NationalPolicing-Hate-Crime-strategy.pdf

University of Sussex and Demos (2018). Patterns of Hate Crime, Who, What, When and Where? [Online]. Available at: https://www.demos.co.uk/wpcontent/uploads/2018/08/PatternsOfHateCrimeReport-.pdf (Accessed $4^{\text {th }}$ March 2021).

Ybarra, M. L., Mitchell, K. J., \& Korchmaros, J. D. (2011). National trends in exposure to and experiences of violence on the Internet among children. Pediatrics, 128(6), 13761386. https://doi.org/10.1542/peds.2011-0118

Zeileis, A., Kleiber, C., Krämer, W., \& Hornik, K. (2003). Testing and dating of structural changes in practice. Computational Statistics \& Data Analysis, 44(1-2), 109-

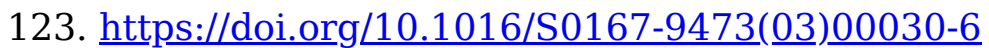

\section{Figure}



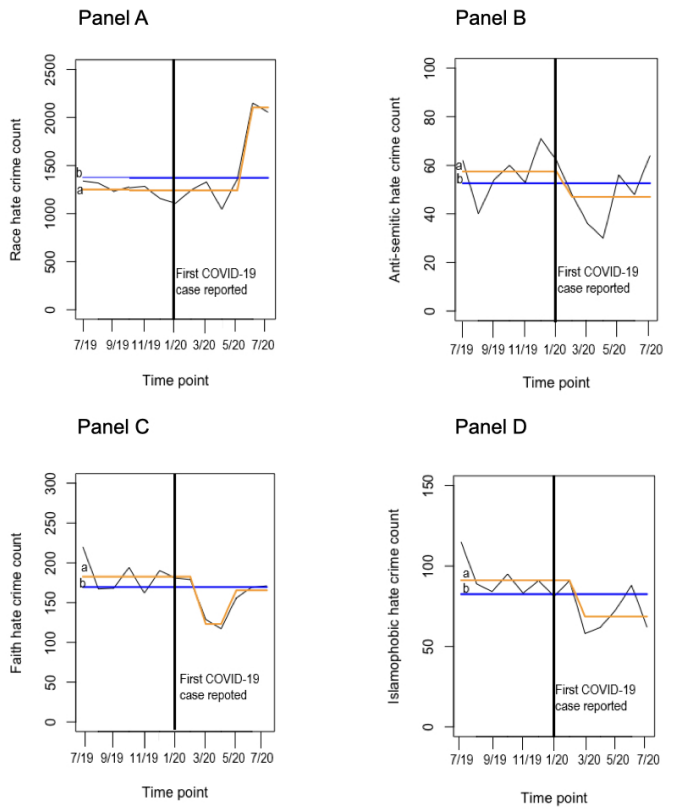

Figure 1. Fitting intercept-only and breakpoint models on observed data for all four hate crime types.

\section{Tables}

Table 1: Racist and Religious Hate Crime Counts in London

\begin{tabular}{|c|c|c|c|c|c|c|c|c|c|c|c|c|c|}
\hline $\begin{array}{l}\text { Hate } \\
\text { crim } \\
\text { e } \\
\text { type }\end{array}$ & $\begin{array}{l}\text { Jul } \\
201 \\
9\end{array}$ & $\begin{array}{l}\text { Aug } \\
201 \\
9\end{array}$ & $\begin{array}{l}\text { Sep } \\
201 \\
9\end{array}$ & $\begin{array}{l}\text { Oct } \\
201 \\
9\end{array}$ & $\begin{array}{l}\text { Nov } \\
201 \\
9\end{array}$ & $\begin{array}{l}\text { Dec } \\
201 \\
9\end{array}$ & $\begin{array}{l}\text { Jan } \\
2020\end{array}$ & $\begin{array}{l}\text { Feb } \\
2020\end{array}$ & $\begin{array}{l}\text { Mar } \\
2020\end{array}$ & $\begin{array}{l}\text { Apr } \\
2020\end{array}$ & $\begin{array}{l}\text { May } \\
2020\end{array}$ & $\begin{array}{l}\text { Jun } \\
2020\end{array}$ & $\begin{array}{l}\text { Jul } \\
2020\end{array}$ \\
\hline $\begin{array}{l}\text { Anti- } \\
\text { Semi } \\
\text { tic }\end{array}$ & 62 & 40 & 54 & 60 & 53 & 71 & 62 & 48 & 36 & 30 & 56 & 48 & 64 \\
\hline Faith & 220 & 167 & 168 & 194 & 162 & 190 & 181 & 179 & 129 & 117 & 156 & 169 & 171 \\
\hline $\begin{array}{l}\text { Isla } \\
\text { mop } \\
\text { hobic }\end{array}$ & 115 & 89 & 84 & 95 & 83 & 91 & 81 & 91 & 58 & 62 & 73 & 88 & 62 \\
\hline Race & 1330 & 1308 & 1222 & 1266 & 1282 & 1157 & 1106 & 1242 & 1329 & 1045 & 1357 & 2148 & 2056 \\
\hline
\end{tabular}

Table 2: Model Fit Indices 


\begin{tabular}{|c|c|c|c|c|c|}
\hline $\begin{array}{l}\text { Hate crime } \\
\text { type }\end{array}$ & Model & AIC & BIC & MAE & RMSE \\
\hline \multirow[t]{2}{*}{ Race } & Intercept-only & 191.15 & 192.28 & 224.33 & 323.51 \\
\hline & $\begin{array}{l}\text { Structural } \\
\text { breakpoint } \\
(1 *)\end{array}$ & 159.75 & 161.45 & 73.45 & 89.53 \\
\hline \multirow[t]{2}{*}{ Anti-Semitic } & Intercept-only & 104.26 & 105.39 & 9.40 & 11.44 \\
\hline & $\begin{array}{l}\text { Structural } \\
\text { breakpoint } \\
\left(1^{*}\right)\end{array}$ & 103.25 & 104.94 & 8.20 & 10.19 \\
\hline \multirow[t]{2}{*}{ Faith } & Intercept-only & 125.08 & 126.21 & 18.19 & 25.48 \\
\hline & $\begin{array}{l}\text { Structural } \\
\text { breakpoint } \\
\left(2^{*}\right)\end{array}$ & 114.19 & 116.45 & 10.99 & 14.37 \\
\hline \multirow[t]{2}{*}{ Islamophobic } & Intercept-only & 111.48 & 112.61 & 11.74 & 15.10 \\
\hline & $\begin{array}{l}\text { Structural } \\
\text { breakpoint } \\
\left(1^{*}\right)\end{array}$ & 103.76 & 105.46 & 7.93 & 10.39 \\
\hline
\end{tabular}

Note. $*$ indicates number of breakpoints.

Table 3: Characteristics of Hate Crime/Incidents Since 1 February 2020

\begin{tabular}{|c|c|c|c|}
\hline & $\begin{array}{l}\text { Reported frequency - } \\
\text { whole sample }\end{array}$ & $\begin{array}{l}\text { Reported frequency - } \\
\text { Chinese and East } \\
\text { Asian participants }\end{array}$ & $\begin{array}{l}\text { Reported frequency - } \\
\text { other participants }\end{array}$ \\
\hline Time of Incident & $\mathbf{N}=\mathbf{2 8 7}$ responses & $\mathrm{N}=182$ responses & $\mathrm{N}=105$ responses \\
\hline February 2020 & $16.08 \%$ & $20.32 \%$ & $8.57 \%$ \\
\hline
\end{tabular}




\begin{tabular}{|c|c|c|c|}
\hline 1.-23.3.2020 & $30.77 \%$ & $34.07 \%$ & $24.76 \%$ \\
\hline 24.3.-13.5. 2020 & $23.78 \%$ & $24.18 \%$ & $22.86 \%$ \\
\hline since 14.5. 2020 & $9.44 \%$ & $6.04 \%$ & $15.24 \%$ \\
\hline Unsure & $19.93 \%$ & $14.80 \%$ & $28.57 \%$ \\
\hline No Answer & $0 \%$ & $0.55 \%$ & $0 \%$ \\
\hline \multicolumn{4}{|l|}{ Location } \\
\hline On the street & $32.40 \%$ & $37.36 \%$ & $23.81 \%$ \\
\hline Near home & $10.10 \%$ & $12.09 \%$ & $6.67 \%$ \\
\hline Commercial setting & $18.82 \%$ & $19.23 \%$ & $18.10 \%$ \\
\hline Public transport & $13.24 \%$ & $15.93 \%$ & $8.57 \%$ \\
\hline School or college & $4.18 \%$ & $3.30 \%$ & $5.71 \%$ \\
\hline Parking lot & $2.44 \%$ & $2.20 \%$ & $2.86 \%$ \\
\hline At home & $0.70 \%$ & $1.10 \%$ & $0 \%$ \\
\hline $\begin{array}{l}\text { Online, social media } \\
\text { public setting }\end{array}$ & $13.59 \%$ & $6.59 \%$ & $25.71 \%$ \\
\hline $\begin{array}{l}\text { Online, social media } \\
\text { private setting/ email }\end{array}$ & $0.70 \%$ & $0.55 \%$ & $0.95 \%$ \\
\hline $\begin{array}{l}\text { Comment sections of } \\
\text { news outlets }\end{array}$ & $0 \%$ & $0.00 \%$ & $0 \%$ \\
\hline No answer & $3.83 \%$ & $1.65 \%$ & $7.62 \%$ \\
\hline Crime Type* & $N=299$ responses & $\mathrm{N}=191$ responses & $\mathrm{N}=108$ responses \\
\hline Verbal harassment & $66.89 \%$ & $62.30 \%$ & $75 \%$ \\
\hline Assault with injury & $1.67 \%$ & $1.05 \%$ & $2.78 \%$ \\
\hline
\end{tabular}




\begin{tabular}{|l|l|l|l|}
\hline Assault without injury & $3.01 \%$ & $2.62 \%$ & $3.70 \%$ \\
\hline Robbery & $0.33 \%$ & $0.84 \%$ & $0 \%$ \\
\hline Household crime & $0.67 \%$ & $0 \%$ & $1.85 \%$ \\
\hline Hate incident & $27.42 \%(n=82)$ & $33.51 \%$ & $16.67 \%$ \\
\hline
\end{tabular}

Note. $*$ multiple responses were possible

Table 4: Characteristics of Hate Crime/Incidents before February 2020

\begin{tabular}{|c|c|c|c|}
\hline & $\begin{array}{l}\text { Reported frequency - } \\
\text { whole sample }\end{array}$ & $\begin{array}{l}\text { Reported frequency - } \\
\text { Chinese and East } \\
\text { Asian participants }\end{array}$ & $\begin{array}{l}\text { Reported frequency - } \\
\text { other participants }\end{array}$ \\
\hline Location & $\mathrm{N}=466$ responses & $\mathrm{N}=\mathbf{2 2 8}$ responses & $N=238$ responses \\
\hline On the street & $28.33 \%$ & $30.26 \%$ & $26.47 \%$ \\
\hline Near home & 12.66 & 13.16 & $12.18 \%$ \\
\hline Commercial setting & 10.09 & $10.09 \%$ & $10.08 \%$ \\
\hline Public transport & $14.59 \%$ & $13.60 \%$ & $15.55 \%$ \\
\hline School or college & $12.23 \%$ & $13.60 \%$ & $10.92 \%$ \\
\hline Parking lot & $3.86 \%$ & $2.19 \%$ & $5.46 \%$ \\
\hline At home & $1.93 \%$ & $2.19 \%$ & $1.68 \%$ \\
\hline $\begin{array}{l}\text { Online, social media } \\
\text { public setting }\end{array}$ & $6.44 \%$ & $5.26 \%$ & $7.56 \%$ \\
\hline $\begin{array}{l}\text { Online, social media } \\
\text { private setting/email }\end{array}$ & $4.08 \%$ & $3.95 \%$ & $4.20 \%$ \\
\hline $\begin{array}{l}\text { Comment sections of } \\
\text { news outlets }\end{array}$ & $1.93 \%$ & $2.19 \%$ & $1.68 \%$ \\
\hline No answer & $3.86 \%$ & $3.51 \%$ & $4.20 \%$ \\
\hline
\end{tabular}




\begin{tabular}{|l|l|l|l|}
\hline Crime Type & $\mathbf{N}=\mathbf{2 6 5}$ responses & $\mathbf{N = 1 2 9}$ responses & N=136 responses \\
\hline Verbal harassment & $70.19 \%$ & $68.23 \%$ & $72.06 \%$ \\
\hline Assault with injury & $4.15 \%$ & $2.33 \%$ & $5.88 \%$ \\
\hline Assault without injury & $1.51 \%$ & $1.55 \%$ & $1.47 \%$ \\
\hline Robbery & $2.64 \%$ & $2.33 \%$ & $2.94 \%$ \\
\hline Household crime & $18.49 \%$ & $21.71 \%$ & $15.44 \%$ \\
\hline Hate incident & $3.02 \%$ & $3.86 \%$ & $2.21 \%$ \\
\hline & & & \\
\hline
\end{tabular}

\section{Footnotes}

1. Hate crimes in response to trigger events are a generalisation of what McDevitt and colleagues (2002) refer to as retaliatory hate crimes. The latter are only cases that respond to a hate crime committed against an ingroup member. $\subseteq$

2. The study pre-registration stated that we would only analyse data three months before and after the first reported COVID-19 case. At the time of analysis, more data had become available and we opted to include longer time-series as these are typically preferred. $\leftrightarrows$

3. https://osf.io/ke5rs/?view_only=e65cf3b0723646e78dfda6a97327b2a1

4. https://osf.io/ke5rs/?view_only=e65cf3b0723646e78dfda6a97327b2a1

5. $7.9 \%$ indicated South-East Asian, 3.8\% Bangladeshi, 9.9\% Pakistani, $14.2 \%$ Indian, 3.1\% Other Asian, 6.4\% African, 2.8\% Caribbean, and 1\% Other Black ethnicity. $\doteq$ 